\title{
Una lectura transatlántica de tres imágenes poéticas de México. Nostalgias, exaltaciones y reivindicaciones
}

Juan Pellicer

Universidad de Oslo

Lejos de México, del otro lado del Atlántico, en la vecindad del Ártico, y con la nostalgia cultivada por el paso de no pocos años, busco el calor, el color y el aliento de las letras que han dado fe de la imagen de México a través de los siglos. Pronto aparecen tres textos poéticos ya muy debidamente canonizados por la historiografía literaria: la Grandeza mexicana (1604), de Bernardo de Balbuena, "primer grande obra de nuestra lírica", según Alfonso Reyes (1991: 404); la Rusticatio mexicana (1782), de Rafael Landívar a quien Pedro Henríquez Ureña (88) considera, gracias a dicho texto, "entre los poetas de las colonias españolas, el primer maestro del paisaje, el primero que rompe decididamente con las convenciones del Renacimiento y descubre los rasgos característicos de la naturaleza" americana; y la Visión de Anáhuac - 1519- (1917), de Alfonso Reyes, "el encuentro con el pasado indígena y la conquista literaria del Valle de México", a juicio de Carlos Monsiváis (26).

La Grandeza da cuenta, principalmente, del esplendor de la ciudad de México, con lujo de recursos tanto renacentistas como barrocos, como corresponde a aquella áurea época; ${ }^{1}$ la Rusticatio, redactada en latín e inspirada por las luces de su siglo, describe los trabajos y los días en el campo, y se inscribe dentro del agropecuario género de las geórgicas, mientras que la Visión proyecta las luminosas imágenes del valle de

\footnotetext{
${ }^{1}$ Es la época en la que coinciden el oro del crepúsculo del Renacimiento con el de la aurora del Barroco. Efectivamente, Bruce W. Wardropper (10) insiste en "la continuidad entre Renacimiento y Barroco". Al discutir el problema de donde "encasillar" a Balbuena, Pascual Buxó (202) opina que él lo haría dentro del estilo histórico y la estética del manierismo.
} 
México — "la región más transparente del aire" — bajo el asombro de la mirada de los primeros españoles que ahí llegaron. Los tres textos fueron concebidos bajo los efectos de feroces nostalgias provocadas, cada una, por exilios —unos más forzados que otros - pero de índole diversa: Balbuena, sacerdote enamorado de la espléndida vida de la ciudad de México donde había podido gozar una vida de estudiante sin estrecheces económicas, había sido después encargado de sus deberes parroquiales en la entonces tan lejana, provincial y no muy culta Nueva Galicia; Landívar, por su parte, jesuita guatemalteco cautivado por la maravillosa realidad del agro mexicano, sufrió en la lejanísima Bolonia el destierro, para él vitalicio, al que su orden había sido condenada por Carlos III; Reyes estaba auto exiliado en Madrid a raíz de la violenta muerte de su padre el 9 de febrero de 1913. Los tres textos pueden inscribirse dentro de la que Miguel Ángel Asturias (153) llamaba "literatura de desterrados"; acaso la Grandeza no fuera más que un antecedente de ella, pero la Rusticatio y la Visión ya son ejemplos inconfundibles. Dichos textos, también, entrañan una cierta apología reivindicatoria, en el sentido de que glorifican el valor de lo americano e incluso proclaman, a menudo, principalmente la Grandeza, la superioridad de ciertos aspectos de México en relación con Europa. A la luz de estos textos, voy a ocuparme, lo largo de las páginas siguientes, del fondo y de la forma de estas reacciones y

\section{Perspectivas}

Como en el resto de la América Latina, los tres siglos de vida colonial en México marcan, entre otras muchas cosas, el nacimiento y desarrollo de una peculiar óptica para contemplarnos a nosotros mismos y para ser contemplados desde el mundo "exterior", particularmente desde la metrópoli. Dicha óptica ha sido materia de estudio para la crítica postcolonialista de nuestros días que ha podido estudiar el diálogo que se produce mediante la yuxtaposición de las perspectivas que han servido para identificar y definir a las naciones que desde del siglo XIX comenzaron a liberarse de su condición colonial.

A mediados del siglo pasado, Edmundo O'Gorman encendió una nueva luz sobre un campo histórico que tradicionalmente se había estudiado a la sombra de rubros tales como "descubrimiento", "conquista", "invasión” y "colonización" de América. Esa nueva luz consistió en plan- 
tear la noción de "la invención de América" a partir de las circunstancias históricas y culturales que determinaron, desde el siglo XVI, la reflexión eurocéntrica sobre la idea del descubrimiento de América y sus consecuencias correspondientes. En efecto, el historiador mexicano concluye que desde la antigüedad helénica y latina, en el mundo conocido entonces, ya Europa ocupaba "el más alto peldaño [...] no por razones de riqueza [...] sino porque se estimaba como la más perfecta para la vida humana o [...] para la realización plenaria de los valores de la cultura" (147-48). El Cristianismo fácilmente se aprovecha, a su manera, de tal jerarquía "y los valores y las creencias de la civilización europea se ofrecen como paradigma histórico y norma suprema para enjuiciar y valorar las demás civilizaciones". Es así que O’Gorman (151) reconoce que, en esas circunstancias, a América no le quedaba otro remedio más que ser consecuente con el liderazgo histórico asumido por Europa durante siglos y someterse al destino de "realizar en América otra Europa": en eso consistió su invención.

Lo demás ya lo sabemos: al imponerse arbitrariamente otra cultura —lengua, religión, derecho, sistema político y económico, principios morales y estéticos, etc.- - se privilegió la vía imitativa, es decir, la reproducción de modelos metropolitanos y la discriminación de modelos originales americanos. Bajo esa tensión fue gestándose la cultura criolla, algunos de cuyos rasgos más o menos peculiares contribuyen a perfilar, en distintos grados, el carácter de los textos de Balbuena y de Landívar; me refiero, especialmente, a algunas de las características de "la modalidad criolla" que apunta O'Gorman (155), tales como "el desaforado y genial abuso de ciertas formas hispánicas de la expresión plástica y literaria [...]; la delirante exaltación de verdaderas o supuestas excelencias naturales y morales propias". La vía imitativa, sin embargo, estuvo lejos de ofrecer un tránsito directo, simple y único; proliferó un eficaz sincretismo, que mucho tuvo de estructural, gracias a las ventajas que pudo rendir principalmente en el terreno de la conversión religiosa y en el de la organización central del poder; el lenguaje, por su parte, especialmente el poético, iba a encontrar, por el camino de la vía imitativa, peculiares retos impuestos por una realidad a menudo distinta a la europea. Por ejemplo, cuando Alejo Carpentier (68) explica su noción de "lo real maravilloso" como lo insólito que en América "siempre fue cotidiano" y como algo inherente al momento en el que los españoles contemplan por primera vez la naturaleza americana y el espectáculo que ofrecen sus paisajes y sus gentes. 
Efectivamente, también recuerda el escritor cubano que cuando los españoles llegaron a México, el área urbana de París era de trece kilómetros cuadrados y la de Madrid, en 1889, de veinte kilómetros, mientras que el área de la ciudad de México-Tenochtitlan en 1519 era de cien kilómetros cuadrados. Cierto, los maravillados conquistadores-cronistas se encontraron con un reto al que se seguirían enfrentando los escritores americanos siglos después: la búsqueda del lenguaje apropiado para una realidad diferente, es decir, la apropiación del lenguaje, o quizás mejor dicho, su expropiación.

Me interesa ahora señalar que el proceso de la apropiación o expropiación del lenguaje poético a lo largo de su tránsito por la vía imitativa sugiere la complejidad del propio proceso pues éste aparece atrapado en su propia paradoja. Es este, a mi juicio, un síntoma o indicio de lo que actualmente se entiende como conciencia postcolonial, es decir, la reflexión crítica, tanto del colonizado como del colonizador, sobre la dinámica de la invención de lo colonizado o colonizable por parte del colonizador o según él. En dicha invención está implícito el poder del lenguaje para construir y dominar el mundo colonizado. En este sentido, la tensión de la experiencia postcolonial está presente en América desde el siglo XVI, es decir, desde que la propia América aparece como factor crucial en la imaginación de Europa que es también el tenso instante cuando se reconoce, y también cuando se pone en tela de juicio, el dominio hegemónico de la verdad universal, es decir, la de Europa (Ashcroft: 17-19). Se trata efectivamente de un diálogo entre el colonizador y el colonizado. La Grandeza y la Rusticatio no podían escaparse a la tensión referida arriba. Y aunque la Visión fue redactada casi cien años después de consumada la independencia de México, el espíritu del colonizador y el del colonizado, como suele suceder en este tipo de relaciones post-coloniales, estaban aún lejos de desaparecer. En el lenguaje poético de cada uno de los tres textos se cifran sendos instantes del diálogo aludido que comentaré adelante, en primer lugar al evocar a

\section{BALBUENA}

Sus biógrafos acometen la empresa de relatar la vida Bernardo de Balbuena y la de Rafael Landívar pertrechados no siempre por la fuerza de fuentes y evidencias que hagan prueba plena pues son muy escasas, sino las más de las veces, por conjeturas probables que muchas veces se desprenden de lo que sugieren sus propios textos poéticos o de lo que podría esperarse 
razonablemente de los autores, conociendo su carácter, en el medio en el que moraron y frente a los eventos que vivieron. En el caso de Balbuena, contamos con una amena biografía seguida por una etopeya que debemos a la agudeza de la fina e irónica pluma de José Rojas Garcidueñas quien documenta el retrato del autor a partir de una minuciosa investigación que incluye además de una amplia bibliografía, el comentario crítico a los estudios de John Van Horne ${ }^{2}$ sobre la vida y la obra de Balbuena que hasta entonces estaban considerados como los más importantes. $^{3}$

La vida de Balbuena pertenece al contexto histórico que comenzaba a armarse en el incipiente mundo colonial. En efecto, Balbuena nació en 1562 en el pueblo manchego de Valdepeñas; a los dos años de edad se lo llevó su papá a la Nueva Galicia donde, como buen indiano que era, "tenía situación relevante y próspera” (Rojas Garcidueñas: 4). Balbuena se crió en la Nueva España donde vivió permanentemente hasta 1606, o sea, hasta los cuarenta y cuatro años de edad (y simétricamente algo muy parecido era lo que pasaba con el país en esos días cuando comenzaba a gestarse la cultura criolla que no era sino el muy reciente traslado y acomodo de la española en las nuevas colonias). "En su corazón de gran poeta”, advierte Alfonso Reyes (1960b: 340), "se confundían el amor de sus dos patrias y el orgullo de las dos distintas grandezas" y así logró dominar el "arte de componer en un solo cuadro dos mundos diferentes”. Entonces pasó el joven Balbuena aproximadamente cinco años estudiando artes y teología en la ciudad de México, época que dejaría imborrable huella en el alma del escritor donde se alojó tanto el gusto por la urbe capitalina como el recuerdo del único, el más que único, amor de su vida, doña Isabel Tovar y Guzmán, que es precisamente a quien está dirigida la Grandeza.

Aficionado a las letras desde la infancia, Balbuena fue premiado en la capital del virreinato en brillantes justas literarias, lo mismo en honor del Santísimo Sacramento que del arribo de nuevos virreyes. Así se trasladaba el brillo del Siglo de Oro de las letras metropolitanas a la colonia. Concluidos sus estudios en la capital y ordenado sacerdote, llegó la hora

\footnotetext{
${ }^{2}$ Son tres los estudios: uno sobre El Bernardo (1927), otro sobre La Grandeza (1930) y una biografía y crítica (1940).

${ }^{3}$ Hay que mencionar también un artículo de José Pascual Buxó, discípulo de Rojas Garcidueñas, que echa luz sobre la interpretación de ciertas cifras en los textos de Balbuena y sobre las relaciones transtextuales entre ellos.
} 
de volver a la provincia para encargarse, gracias a influencias familiares, de modestos curatos pueblerinos en la Nueva Galicia que le dejaron buen tiempo para escribir (principalmente la mayor de sus obras, un extenso poema épico en octavas reales, El Bernardo o Victoria de Roncesvalles) y que aunque le permitieron darse frecuentes escapadas a Guadalajara y a otras ciudades de la provincia, también lo habrán hecho extrañar las delicias urbanas propias de la capital.

Volvió a ver a doña Isabel en San Miguel de Culiacán, apenas comenzado el nuevo siglo, ya viuda y seguramente feliz de por fin poder disfrutar el ejercicio de su libertad al decidir recluirse en el riguroso claustro de un convento de la ciudad de México al que se dirigiría próximamente; ella le pidió entonces a su viejo cuanto imposible amor que le contara cómo era la ciudad de México, acaso sólo para saber de lo que se iba a perder gracias a su vitalicio encierro, o quizás para muy platónicamente, como correspondía a la relación que los unía, poder mirar la ciudad tan sólo así, por mero reflejo, a través de los ojos ideales de él. Efectivamente, más tardó ella en formular su encarecimiento que Balbuena — cual sediento invitado a beber, según él mismo confiesa en la introducción a su poema-carta - en redactar una desaforada carta, formada por tercetos endecasílabos, en la que trazó "una especie de topografía poética" (Menéndez Pelayo: 58) que acaso sea el más espléndido retrato directo de la magnífica ciudad colonial. La carta se publicó en 1604, en México, bajo el título de Grandeza mexicana.

En 1606, o sea, cuarenta y dos años después de haber salido, volvió Balbuena a España con la intención de gestionar y obtener un buen puesto que no había logrado conseguir en México. Ese mismo año fue designado Abad de la entonces remotísima Jamaica. Once años después fue ascendido y nombrado Obispo de Puerto Rico donde comenzó a desempeñar su cargo en 1623. Un año después se publicó en España El Bernardo, que fue su obra predilecta. Sin haber regresado nunca más ni a la nueva ni a la vieja España, el padre Balbuena, "el verdadero patriarca de la poesía americana”, según Marcelino Menéndez Pelayo (62), murió en 1627 en San Juan de Puerto Rico.

"La principal contribución de la América española al barroco, en literatura, llegó a través de Valbuena [sic]", sentencia Henríquez Ureña (76), y agrega: "Su estilo es pródigamente ornamental, pero su estructura sigue siendo simple, como en la arquitectura barroca mexicana". Y así lo ilustra el ensayista dominicano: "Su Bernardo, por el que aspiraba 
a ser el Ariosto español, es comparable, en su magnitud, al Convento de Tepozotlán; su Grandeza Mexicana, al Sagrario de la Catedral de México". El elocuente símil sugiere la coincidencia del transplante del estilo arquitectónico con el del literario, y también el carácter de invención que ostenta el transplante en el sentido que a esta noción le atribuye O'Gorman. Por su parte, Reyes aclara la idea ajustando su enfoque: "Balbuena se adelanta al churrigueresco, así como entra en las revoluciones poéticas del Siglo de Oro por caminos independientes" (1960b: 341). En efecto, Balbuena se adelanta a los estilos importados, participa por su cuenta y sin alinearse en las innovaciones de la época, y su reflexión desmiente el tópico de la "exhorbitancia americana". Si es cierto que la

\section{GRANDEZA MEXICANA}

cabalga, por su estilo y por su época, entre el aliento renacentista del siglo XVI y el barroco característico del XVII, también es cierto que, como veremos más adelante, predomina lo barroco. No conozco otra introducción a la lectura de este texto ni más certera, ni más completa, ni más concisa que la de Alfonso Reyes (1960a: 341); como no intentaré mejorarla, prefiero transcribirla:

Su nota característica no está, como se aseguró de memoria, en el ímpetu y la feracidad tropicales (su paisaje es casi siempre erudito), sino en la exaltación de la Polis, de la ciudad, de la obra humana que asea y reedifica la naturaleza. Su fantasía misma se halla estimulada por la templanza del clima y la transparencia del altiplano; la cual, como alguna vez hemos escrito, ofrece el paisaje organizado, donde los ojos yerran con discernimiento, la mente descifra cada línea y acaricia cada ondulación. El colorido y la suavidad no estorban a la osadía y al nervio. Su colorismo no es abigarramiento, y hasta entiende de claroscuro. El mural palpita con el desfile donde nunca hay embarazos de tránsito [...] El terceto no consiente alaridos. El poema mismo está sometido a un programa riguroso y verdaderamente geométrico que, por supuesto, no tiene el mal gusto de respetar al pie de la letra. Consta de nueve cantos en tercetos, y cada canto corresponde a cada uno de los versos de la octava inicial, que viene a servirle de sumario; a excepción del séptimo, el cual por su naturaleza, se divide en dos miembros. Y nótese que se trata del penúltimo endecasílabo, como si el análisis se adelgazara aquí, para luego recoger la síntesis en el canto final: 
De la famosa México el asiento, origen y grandeza de edificios, caballos, calles, trato, cumplimiento, letras, virtudes, variedad de oficios, regalos, ocasiones de contento, primavera inmortal y sus indicios, gobierno ilustre, religión y estado: todo en este discurso está cifrado.

Antes de la octava inicial hay dos dedicatorias: una práctica y una sentimental. Respecto a la primera, vale la pena registrar que la edición príncipe del poema, fechada en 1604, consta de dos tiradas simultáneas; una con dedicatoria a Fr. García de Mendoza, Arzobispo de México, y otra con dedicatoria al Conde de Lemos, Presidente del Real Consejo de Indias. El resto del texto es idéntico en las dos tiradas. Balbuena necesitaba el apoyo de estos personajes claves — uno en la colonia y el otro en la metrópoli- para obtener un deseado ascenso dentro de la jerarquía eclesiástica y un buen lugar donde desempeñar su cargo.

La dedicatoria sentimental obra en la "Introducción" donde da noticia del remoto lugar — San Miguel de Culiacán — donde vivía Doña Isabel Tobar y Guzmán; seguidamente alude a la petición que ella le hace pues quería saber cómo era la ciudad de México. Esta dedicatoria revela, si bien entre líneas pero de modo inconfundible, el amor por ella que, aunque platónico, Balbuena guardaba en su pecho. También revela cuánto admiraba el poeta la "insigne y poderosa ciudad de México" (Balbuena: 56).

Pero lo que ahora quiero destacar es el sentido que tiene la imagen del paisaje del lugar donde ubica a Doña Isabel; en primer término, el lugar es remoto - "en los más remotos confines destas Indias occidentales" (55) —, lo cual en el contexto resulta negativo, pero: ¡es "remoto" en relación con qué? Claro, es remoto en relación con la capital y aún más remoto en relación con la metrópoli. Es decir, lo negativo (remoto) del lugar está definido desde el centro y desde Europa. Pero el lugar no sólo es remoto sino que además Balbuena lo pinta, a la usanza barroca de la época, con "yermas y espantosas soledades [...] desiertas costas y abrasados arenales [...] sordas playas y carcomidas rocas $[\ldots]$ " sobre las que plasma "la temerosa imagen y espantosa figu- 
ra de algún indio salvaje, que en suelta y negra cabellera con presto arco y ligeras flechas [...] sale a caza de alguna fiera menos intratable y feroz que el ánimo que la sigue" (55). El carácter exótico de la imagen del indio salvaje, que prefigura una moda romántica, se enciende aquí con los significantes calificativos de "temerosa", "espantosa", "intratable y feroz" que corresponden simétricamente a los que acaba de usar para pintar la naturaleza. De este modo, lo salvaje de la naturaleza y sus nativos, y su correspondencia recíproca, quedan inventados y valorados negativamente gracias al lente colonial.

El cuerpo del poema que sigue a la octava inicial consta de nueve cantos:

I (Apóstrofe a la destinataria y elogio de la ciudad de México)=71,

II (Arquitectura y trazo de la ciudad) $=57$,

III (Aspecto de las calles y de su tráfico humano y equino) $=61$,

IV (Los oficios y la cultura urbana) $=82$,

$\mathrm{V}$ (Las diversiones y los placeres $)=60$,

VI (El permanente ambiente primaveral) $=60$,

VII (El gobierno y la iglesia) $=62$,

VIII (La religión y sus órdenes) $=70$,

Epílogo (Recapitulación autorreferencial y elogio de la metrópoli)=126.

Por el número de estrofas de cada canto, la distribución traza una línea que desciende y luego asciende hasta el punto más alto, a la mitad, es decir, el canto IV, para después descender y volver a subir y culminar en el Epílogo. La distribución sugiere la importancia del tema al que está dedicado cada capítulo. Los cantos están engarzados mediante la alusión, al final de cada uno de ellos, al tema que tratará el siguiente y también mediante una breve alusión a lo que hasta entonces ha tratado el poema, al principio de cada capítulo. De este modo fluye con ligereza el torrente sobre un lecho en el que se revela la eficacia propia de los tercetos y la destreza del poeta para manejarlos.

El estilo del poema es abigarrado, el tono hiperbólico, lo que corresponde a su aliento barroco; cada canto comienza identificando y definiendo imágenes, comparándolas, agrupándolas, enumerando los objetos descritos por ellas en forma de proliferantes listas que pueblan, colmándolo, el espacio del poema. Ya trátese, por ejemplo, de la variedad de 
gentes, oficios o caballos, su enumeración equivale a las tradicionales letanías. Símiles y antítesis entre diversos oficios, ciudades y tiempos provocan invariablemente resultados ventajosos para la ciudad de México. Mediante símiles favorables, gana comparada, por ejemplo, con Troya, Roma y Venecia, "que México por pasos diferentes / está en la mayor cumbre de grandeza / que vieron los pasados y los presentes” (70). Hípicamente sale victoriosa también México de la justa provocada por el juego de los símiles — ya Balbuena reconoce lo que llegaría a ser la peculiar y rica tradición charra - al comparar la acaso más célebre raza de caballos, la de los ejemplares andaluces - "los que el gran Betis en su arena ensaya" - que no "podrán contrahacer la gallardía, / brío, ferocidad, coraje y gala / de México y su gran caballería” (74).

En efecto, la grandeza de la ciudad de México es incomparable y también inconmensurable, a lo cual también contribuye el fragor de su tráfico comercial como cruce de caminos entre Asia, América y Europa (77). La hiperbólica imagen de la capital de la Nueva España como centro mercantil del mundo parece darle pie al espíritu barroco del poeta para una hipérbole aún mayor, es decir, una hipérbole de otra hipérbole que así reza: "México al mundo por igual divide, / y como un sol la tierra se le inclina / y en toda ella parece que preside" (79).

Los capitalinos son también objeto de hiperbólicos homenajes no carentes de cierta ironía pues no sólo no calla, como dice hacerlo, cualidades que se han vuelto supuestamente características de los capitalinos — gallardía, generosidad, cortesía, suavidad, prodigalidad—, sino que las proclama explícitamente. Ya comenzaban los capitalinos a "inventarse" ante la mirada de Europa, el juez que tenía la última palabra, proclamando su carácter mediante la hipérbole de lo positivo de sus rasgos.

Llaman la atención especialmente dos momentos del poema que presentan sendas oposiciones que se arraigarían entre las estructuras del país en esa época y marcarían el posterior desarrollo no sólo de México sino de la América Latina toda; me refiero a la de la riqueza y la pobreza, y a la de la vida urbana y la rural. Balbuena, cura y buen cristiano, desde su desahogada posición económica y su relativamente alta clase social, condena la pobreza pues, según él, "La pobreza doquiera es vieja en cueros, / abominable, congojosa y fiera, / de mala cara y de peores fueros" (83); sin embargo, implícitamente acepta la existencia de la pobreza como algo que no siendo nuevo, tampoco es exclusivo de México. El poeta no sólo condena ese injusto estado sino también, sin mucha pie- 
dad, a los pobres: "gente mendiga, triste, arrinconada, / que como indigna de gozar el mundo / está dél y sus bienes desterrada" (83). Es significativo que el cristianismo de Balbuena, como seguramente el de sus contemporáneos, reprobara las consecuencias de la pobreza y no sus causas.

La oposición entre la ciudad y el campo, que llegaría a ser central en buena parte del pensamiento latinoamericano del siglo XIX, y particularmente a partir de la reflexión (civilización/ciudad contra barbarie/campo) de Domingo Faustino Sarmiento, ya se perfila en el poema. En pocas palabras, la grandeza de la ciudad capital se mide mejor comparándola con la "estrechez" — léase insignificancia - de la vida del campo o provinciana (84-86). La vía del elogio, que ha transcurrido por el claroscuro de la comparación de la ciudad con el campo, culmina otra vez con dos hipérboles: por una parte, hasta lo imposible se puede conseguir en la capital y, por la otra, su educación superior (seguramente que se refiere a su universidad) está por encima, al menos en cuanto a la calidad de sus letras, de las mejores de Europa.

Abundan las alusiones a la mitología greco latina que bien pueden leerse como recurso común y corriente del lenguaje poético de la época; su ausencia en el poema hubiera resultado extraña. Evidentemente, el lenguaje poético de Balbuena es el que estaba en uso y hubiera sido imposible que usara otro; sin embargo, lo que quiero destacar es que es precisamente el uso lo que impone la óptica colonial. Es también significativo que Balbuena describa una naturaleza formada por elementos que eran propios de la naturaleza europea, es decir, que, por ejemplo, la flora y la fauna descritas en el poema sean las mismas que se encuentran en Europa; efectivamente, en el texto no hay ahuehuetes, ni magueyes, tamales, chocolate, elotes, chiles, guayabas, aguacates, jitomates, cacahuates, tortillas, cempoasúchiles, guanábanas, zapotes, chirimoyas, guajolotes, cenzontles, chachalacas, escuintles, etc. En cambio sí hay laureles, almendros, pinos, jazmines, hayas, olmos, sauces, cipreses, abetos, álamos, encinos, madroños, cedros, nogales, amapolas, rosas, claveles (96-97), peras, uvas, cermeñas, membrillos, manzanas, duraznos, nueces, avellanas, granadas, liebres, conejos, gavilanes, tórtolas, faisanes (92), etc. En el poema abunda el vino pero no se sirve ni aguamiel ni pulque. ¿Quiere decir esto que los españoles, aunque ya mexicanizados como Balbuena, todavía no podían o no se atrevían, casi cien años después de la conquista, a nombrar las cosas que se encontraban en América? ¿Les pasaba todavía lo mismo que a Cortés cuando le escribía a Carlos V? 
¿O es que despreciaban lo originalmente americano como lo hacían con los indios — "el indio feo"—? (124).

Los cantos VII y VIII revelan cuánto la grandeza capitalina debe al gobierno y a la iglesia, instituciones establecidas a la usanza metropolitana; a los elogios, más que hiperbólicos, que el poeta rinde a los virreyes que hasta entonces habían sido, se suman los dedicados a la burocracia y a la iglesia. Balbuena queda bien con sus superiores y así se granjea su codiciado ascenso y la mejoría de su adscripción.

No le falta al poema su comentario —elogioso, por supuesto— a sí mismo que es como empieza el último canto dedicado a una recapitulación de lo tratado a lo largo del poema. Con este clásico remate, el poeta aprovecha la oportunidad para dar fe de que es en México "donde se habla el español lenguaje / más puro y con mayor cortesanía” (115). Pero la grandeza de México-Tenochtitlan que hicieron célebre las plumas de los cronistas, principalmente las de Cortés y Díaz del Castillo, acaba en "chozas humildes, lamas y laguna" gracias a la retórica de Balbuena destinada a complacer a los que ejercían el poder, en ambos lados del Atlántico, quienes podían ayudarlo a conseguir un buen cargo dentro de la jererquía eclesiástica. A fin de cuentas, Balbuena no deja de ver a América con la óptica europea predominante y sigue invocando a España - y no a México donde había crecido y se había educado y cultivadocomo "invencible patria mía" (123) y deseando que "el mundo que gobiernas y autorizas / te alabe, patria dulce, y a tus playas / mi humilde cuerpo vuelva, o sus cenizas" (124). Habrían de pasar aún muchos años, más de siglo y medio, para que los países americanos pudieran llegar a ser identificados como patria no sólo por los indios y los mestizos, sino también por los criollos. Uno de estos habría de ser

LANDÍVAR

Si Balbuena fue nacido manchego pero criado mexicano, Landívar fue un guatemalteco que sintió a México como algo propio; si el primero vive durante el primer siglo del orden colonial, al segundo le tocará ser víctima del principio del desorden del último. En efecto, Landívar nace en 1731 en la capital de Guatemala, en cuna criolla de aristócratas estirpes navarras y castellanas. Estudió primero en su casa, a la usanza de las familias ricas como la suya, con dos maestros de tiempo 
completo para él solo, luego en el colegio jesuita de San Francisco de Borja y finalmente en la Real Pontificia Universidad de San Carlos Borromeo.

Tres años después, en 1749, marcha Landívar a México donde ingresa en el noviciado jesuita de Tepozotlán. Los once años que permanece en México le permiten viajar, conocerlo y disfrutarlo intensa y extensamente gracias a su fina sensibilidad y su sólida formación jesuita tan acorde con el ambiente de las luces que estimulaban la curiosidad sedienta de conocimientos por aquella época; acaso sin saberlo él mismo, en esas excursiones entre los tan variados paisajes mexicanos y los diversos modos de vivir y trabajar en el campo, comenzaba a fraguarse el programa del gran poema que lo inmortalizaría.

De regreso en su tierra en 1762, asume las cátedras de Retórica y Filosofía en su colegio universitario de San Borja del que llega a ser Rector. Ahí estaba cuando Carlos III, en 1767, resolvió expulsar a los jesuitas de España y de sus colonias. El penoso itinerario de la vía del destierro de Landívar hacia el exilio pasó por Cuba rumbo a Cádiz, y luego de seis meses en Ajaccio, acabó de llegar, en 1768, a su final destino: Bolonia. En el noviciado de La Sapienza, fue nombrado Superior, gusto que no le duraría mucho pues Clemente XIV suprimió la Compañía en 1773. Entonces se dedicó a escribir y a completar los cinco mil trescientos cuarenta y ocho hexámetros que componen la versión definitiva de la Rusticatio publicada en Bolonia en 1782 (una primera versión, de menor extensión — tres mil trescientos veintisiete hexámetros-, había sido impresa en Módena un año antes). Sin haber regresado nunca más a su patria, el padre Landívar, "el Virgilio de nuestra poesía” según Reyes (1991: 414), murió en 1793 en Bolonia.

Landívar pertenece a aquella brillante generación de jesuitas americanos exiliados a quienes se les atribuye el despertar de una conciencia americana propia y cuyos textos geográficos, etnográficos, históricos y literarios entrañan ya una inconfundible reflexión anticolonialista inspirada por "la reivindicación de la cultura prehispánica, el sentido de la nacionalidad mexicana, y por último, el auge de la cultura clásica" (Reyes 1960b: 375). En La cultura hispano-italiana de los jesuitas expulsos, Miguel Batllori nos brinda un muy pormenorizado panorama de la circunstancia histórica de los jesuitas españoles, hispanoamericanos y filipinos exiliados en Italia. Dicha circunstancia registra la publicación por esos años de ciertos textos europeos que provocaron las 
reacciones nacionalistas de los jesuitas. El propio Batllori (581) observa cómo la Histoire naturelle de Buffon, el Essai sur les moeurs de Voltaire, las Recherches philosophiques sur les Américains de Cornelius de Pauw, la Histoire philosophique et politique des établissements et du commerce des Européens dans les deux Indes del abate François Raynal, y la History of America de William Robertson, "desvalorizaban la obra colonizadora de España y Portugal, la labor evangélica de los jesuitas, la naturaleza misma del nuevo continente y las cualidades humanas de las razas indígenas".

Los jesuitas de aquella época, que "representan una fase regionalista prenacional" (Batllori: 579), rechazaron esta nueva expresión eurocéntrica de la invención de América por medio de una incipiente pero vigorosa reflexión americanista y desde varios frentes: el histórico, el etnográfico, el lingüístico y el poético. Dichos textos retratan la maravillosa realidad de la naturaleza americana presentada, con espíritu reivindicatorio, algunas veces como "superior" a la europea o al menos como muy diversa, pero siempre iluminada por el solitario faro de una nostalgia ya muy romántica. En efecto, la Rusticatio apareció como una orgullosa afirmación de la belleza natural y de la riqueza de la América rural, de la abundancia y calidad de sus productos agropecuarios, y de la destreza industrial y capacidad intelectual de sus habitantes (Kerson: 587). Por su parte, Miguel Ángel Asturias (154) precisó aún más específicamente el valor de esa "orgullosa afirmación" cuando fue a Estocolmo a recibir el Premio Nobel:

hay algo que debemos señalar en el canto landivariano: su amor al nativo. Canta en el indio a la raza que en todo sale airosa [...] Así va dejando substancia poética, poesía naturalista ajena a lo simbólico, de un hecho que siempre ha querido negarse: la superioridad del indio americano como campesino, artífice y obrero [...]. A la pintura del indio malo, haragán y vicioso, tan propalada en Europa y tan creída en América por los americanos que lo explotan, Landívar opone la estampa del indio sobre cuyos hombros ha pesado y sigue pesando el trabajo en América.

No ha dejado de llamar la atención que el poema se escribiera en latín; Luis Cardoza y Aragón, molesto por "la sotánica retórica" (607) de Landívar, lo acusa porque "recurrió a la lengua desechada por Dante, con el propósito de alejar más de su lectura a su pueblo analfabeto" (140). Lo que sí es cierto es que entre los jesuitas en particular, y en el ámbito intelectual en general, el latín era entonces lingua franca. "El apogeo de la 
latinidad es, sin duda", advierte Reyes (1960b: 376), "la característica más singular de la época [...], en el siglo XVIII el latín deja de ser una lengua muerta [...] No sólo se vuelve cosa propia por la maestría con que se lo cultiva, sino por el decidido espíritu mexicano de nuestros humanistas". Reyes contempla la lengua latina como algo hecho propio o naturalizado —expropiado - precisamente por el "espíritu mexicano" que animaba a los jesuitas. Cierto, estos nuevos latinistas representan, como hemos dicho, una toma de conciencia nacionalista; rechazaron la invención de América de los europeos que desde el otro lado del océano ignoraban o menospreciaban su realidad; en cambio, proyectaron en Europa una imagen de América vista por ojos americanos pero paradójicamente expresada por medio de un discurso latino, es decir, eminentemente europeo. Si Landívar escribe en latín y no en español es tanto por tradición como por subversión; en efecto, la corona española los había podido expulsar arbitrariamente de su propia tierra, mas no de su tradición: acaso esta injusticia contribuyó también a que los jesuitas prefirieran el latín al español.

No, no se podía arrancarles su tradición y el mundo latino era central en ella. Ahí estaba Virgilio, nuevamente de moda en la Europa del siglo XVIII, particularmente sus Geórgicas, el modelo primero de la Rusticatio, pero también se encuentran reminiscencias de otras obras latinas. Sin embargo, muy probablemente es el Praedium Rusticum (1706 y 1730) del francés Jacques Vanière - también jesuita y neolatino como Landívar-, el modelo más directo de la Rusticatio. Con seguridad, el Praedium habrá sido predilecta lectura de Landívar pues el epígrafe de la Rusticatio está tomado de aquél; hay además una alusión explícita a su hermano de armas francés en el libro décimotercero dedicado a las aves, cuando al referirse a las gallinas, el poeta se pregunta retóricamente quién se atrevería a cantarlas después de que Vanière ya lo había hecho con el aplauso de Febo y ganándose la aonia corona, es decir, con la mayor fortuna (185). Adviértase además que a los quince cantos del Praedium, equivalen los quince de la Rusticatio (algunos de cuyos títulos son semejantes), y que a la utópica sociedad que representan las abejas en el poema de Vanière corresponde la de los castores en el de Landívar. ${ }^{4}$

\footnotetext{
${ }^{4}$ No he encontrado un estudio comparativo entre el Praedium y la Rusticatio; Kerson (590) sugiere que hay semejanza de palabras, de recursos poéticos, de escenas dramáticas y de luchas épicas de animales humanizados.
} 
La Rusticatio queda incorporada en la tradición americana y si es cierto que contribuye a lo que hoy llamamos invención de América por medio de la vía imitativa, también es cierto que asimismo contribuye al proceso de naturalización americana del tema y su medio de expresión. Es significativo que Alfonso Reyes (1960a: 166), un día que platicaba con el Presidente de la República, de cuestiones relacionadas con el gobierno, le sugiriera que

se recomendara en las escuelas agrícolas - y de modo general en las escuelas primarias - la lectura de las Geórgicas para despertar en la mente de los niños la vocación del campo, vocación que hoy casi se confunde con la vocación de la patria [...] la lectura se acompañaría con fragmentos de nuestras Geórgicas, o sea la Rusticación mexicana de Landívar [...] para hacer sentir así, de un modo palpable, cómo el espíritu clásico puede acercársenos y hasta tener utilidad nacional.

La sugerencia de Reyes no obedece solamente a la admiración de un poeta por un gran poema, sino que se ajusta al espíritu práctico, eminentemente didáctico, que anima al género de las geórgicas y particularmente a la

\section{RUSTICATIO MEXICANA}

Arnold L. Kerson (589), al comentar el poema, nos recuerda que la palabra "rusticatio" significa "vida del campo" y también "agricultura". Como su género lo exige, la Rusticatio presenta a menudo escenas pastorales y cómico-heroicas, e incluye no sólo material agropecuario sino que también se ocupa de la minería, de los pájaros, de los animales salvajes y domésticos, de diversas industrias del campo y, además, de actividades escenificadas en el campo de la frontera que une y separa lo urbano y lo rural, como lo son las corridas de toros, las carreras de caballos y las peleas de gallos. El poeta recurre frecuentemente, también con espíritu virgiliano y vanieriano, a la personificación de cosas y de animales, atribuyéndoles rasgos humanos nobles y sentimentales; así sugiere explícitamente la correspondencia de la calidad de vida, la de los castores por ejemplo, con la que se presentaba en los proyectos utópicos, tan caros a los jesuitas de las reducciones, a partir del de santo Tomás Moro. 
El poema ${ }^{5}$ comienza con una dedicatoria seguida por un breve prólogo - Monitum —; la dedicatoria a la Vrbi Guatimalae está compuesta por 17 dísticos distribuidos en 4 estrofas. Es una apóstrofe cuyo primer verso define, como la clave musical que inicia las partituras, el tono y el sentido del poema: Salue, cara Parens, dulcis Guatemala, salue. Este verso es una clara alusión al 173 del Libro II de las Geórgicas que es casi igual: 'salve, magna parens frugum, Saturnia tellus'. Cierto, pero aunque formalmente imite a Virgilio, el verso de Landívar materialmente traslada el amor a Roma a Guatemala y así revela una clara conciencia nacional y patriótica, un sentimiento americano nuevo que anuncia una también nueva época de nuestra historia.

El prólogo, en prosa, incluye 5 notas que confirman que el padre Landívar estaba escribiendo para lectores europeos y especialmente para los que ignoraban cuál era la realidad americana. Desde luego que el autor está conciente de la dificultad que entraña el uso del latín pero también de que las cosas americanas, en cualquier lengua, son difíciles de comprender para los europeos. La reflexión de Landívar es sintomática y va a ser central en el diálogo de los siglos XIX y XX entre americanos y europeos.

Como ya he mencionado, el cuerpo del poema está formado por 15 cantos y un apéndice. Al paisajismo predominante de los primeros cantos sigue un ascendente dramatismo que culmina con la tan humana, ejemplar y trágica vida de los castores, para luego, como si se tratara de un intermedio precisamente a la mitad del poema, presentar la fría e inhumana mecánica de la minería, y después repetir el orden hasta terminar con una final recapitulación bajo el signo de la Cruz de Tepic.

Cada canto repite simétricamente un ordenado desarrollo a partir de un Exordium o Propositio seguido por una breve referencia al Argumentum y por una Invocatio a los que sigue el propio cuerpo del canto. De este modo, inmediatamente después del exordio del primer canto, el dedicado a los lagos mexicanos, y antes de la invocación, se presenta, bajo el subtítulo de Totius carminis argumentum, el índice temático de todo el poema, y la Scribendi causa que no es sino la muy dramática expresión del profundo dolor causado por el exilio. La primera imagen de la tierra y del agua en el poema es la de la ciudad de México, una visión de la ciudad

\footnotetext{
${ }^{5}$ Me refiero siempre a la segunda edición, la definitiva, es decir, a la de Bolonia de 1782.
} 
muy diferente de la que presentó la Grandeza de Balbuena; diferente no porque la ciudad hubiera crecido y cambiado en los casi dos siglos que separan a los dos poemas, lo cual también es cierto, sino por la distinta óptica que usó cada poeta; mientras que Balbuena se refiere al antiguo México, al prehispánico, como "chozas humildes, lamas y laguna", y a su posterior grandeza como efecto directo del imperio hispano (121), Landívar glorifica la soberbia ciudad antigua y su legítima soberanía indígena a la vez que apunta que España la ha dominado por la fuerza de las armas, es decir, ilegítimamente.

En efecto, el sentimiento del jesuita criollo Landívar del último tercio del siglo de las luces, cuando ya los criollos identifican a su patria con América, es muy otro que el del cura criollo Balbuena del recién entrado siglo XVII, cuando llama a España su patria. En el alma de Landívar, la grandeza de México tiene un origen prehispánico, mientras que en la de Balbuena la grandeza es eminentemente hispánica. Las dos perspectivas, con sus resonancias culturales en general, y jurídicas y políticas en especial, son representativas de sus correspondientes épocas, sobrevivirán el paso de los siglos e inspirarán buena parte del debate postcolonial de nuestros días.

El espacio del presente ensayo imposibilita la realización de una lectura pormenorizada del poema, ${ }^{6}$ pero al mismo tiempo resulta imposible no detenerse, al menos brevemente, frente a unas cuantas escenas que resultan imprescindibles para saborear aunque sólo sea una probada del texto. Me refiero a las chinampas, la grana, los castores, las fuentes y los juegos. Acaso ningún otro ejemplo se ajuste más a lo que entendía Carpentier por real maravilloso, como la rica descripción que pinta la Rusticatio del paisaje del valle de México, las aguas transparentes de sus arroyos, canales y lagos, sus volcanes perpetuamente nevados, y principalmente sus increíbles — reales y maravillosas- agri fluitantis (19) quos Indi patrio dicunt sermone Chinampas (16). Landívar, con el espíritu épico característico del género de las geórgicas, relata la gran leyenda del origen y el funcionamiento de la agricultura que se desarrolla flotando en

\footnotetext{
${ }^{6}$ Anthony Higgins, en Constructing the Criollo Archive: Subjects of Knowledge in the Bibliotheca Mexicana and the Rusticatio Mexicana, llevó a cabo un estudio que ha echado nueva luz sobre numerosos aspectos de la Rusticatio, particularmente a partir de la neoclásica noción de lo "sublime". También el trabajo de Andrew Laird, en The Epic of America: An Introduction to Rafael Landivar and the Rusticatio Mexicana, es una nueva y valiosa contribución a los estudios sobre la Rusticatio, especialmente sobre su contexto histórico y su recepción.
} 
las chinampas; no hace falta mucha imaginación para darse cuenta del asombro que el texto iba a provocar entre sus lectores europeos. El relato revela la profunda admiración de Landívar por las antiguas civilizaciones indígenas americanas, y por el ingenio y el arrojo de sus gentes.

Arriba me referí a la personificación de los animales a la que el autor recurre para presentar épicamente la vida ejemplar de aquéllos, principalmente la de las cochinillas y la de los castores, con una afortunada mezcla de idealismo y de realismo. El cuarto canto está dedicado, en primer lugar, al proceso industrial de la grana y al cultivo del nopal que es donde se alojan las cochinillas. En la segunda parte, el poema se refiere a la púrpura que se extrae de un molusco que vive en las rocas de la bella costa de Nicoya. Es cierto que el texto no ennoblece al molusco de la púrpura humanizándolo, pero sí a la cochinilla de la grana. Efectivamente, luego de ocuparse minuciosamente del cultivo del nopal, el poema describe el modo de ser y las costumbres de las cochinillas, los peculiares rasgos que caracterizan a los machos y a las hembras, su procreación, sus enemigos, el delicado cuidado de sus crías, y finalmente su necesario sacrificio. En este breve relato cabe toda una lección moral del humanismo de la época cuyos principios evocan los que regulan la convivencia armónica de los proyectos utópicos asociados con el mundo americano y muy especialmente los que inspiraron las célebres reducciones jesuitas: la íntima y feliz relación del hombre con la naturaleza en la que halla suficiente y sano sustento, la inocencia y la glorificación de la noble estirpe, el rechazo a la guerra entre hermanos y a los tumultos, el amor al hogar, a la familia y al ámbito doméstico, y lo que acaso resulta más significativo dentro del contexto colonial español en el que se generó, inventándolo a raíz de la conquista, el derecho de gentes: la condena a los que han invadido a otros pueblos, especialmente a los más débiles.

Pero tal vez sea en la narración y descripción de la vida de los castores, en el canto VI, donde el retórico recurso de la humanización de los animales alcance su mayor eficacia en el cuerpo del poema. Los mismos nobles rasgos que caracterizaron la naturaleza de las cochinillas van a atribuirse a los castores, pero ahora se añadirá — espejo de la Ilustración predominante- la descripción y el comentario relativos a la habilidad y la destreza de estos animales para proyectar y construir ciudades bien fortificadas, para construir sus casas y mantenerlas ordenadas y debidamente aseadas, más resplandecientes que las de los hombres ricos (85), para diseñar sistemas de diques y puentes, para recoger y preparar sus 
materiales de construcción, todo mediante un disciplinado esfuerzo común, en equipo, organizado por una rigurosa división del trabajo. El poema también revela el cuidado que los castores deben a los viejos y a los débiles, el respeto a los castores que han elegido la vida solitaria, la sabia observancia del ahorro, la astucia propia de estos animales para defenderse de sus enemigos, y la no menos sabia institución de la propiedad común de todas las cosas.

El canto XII se ocupa de las fuentes, es decir, de algunos de los más conocidos ojos de agua que hay en México (Zapopan, Uruapan, Ixtlán, Tehuacán y otros). El catálogo principia con la descripción del milagroso manantial que brota en el cerro del Tepeyac donde se encuentra el santuario de la Virgen de Guadalupe. Adviértase que dicho templo, el más célebre de cuantos hay en México por su significación cultural, no lo menciona la Grandeza al referirse a las más importantes iglesias de México, lo cual confirma que el culto guadalupano es posterior a esa época. En cambio, entrado el siglo XVIII, según la Rusticatio, la Guadalupana ya está entronizada como Caelitum Regina y su fama de bienhechora se ha extendido, especialmente por las milagrosas propiedades curativas del manantial, regalo de ella que ahí dejó como recuerdo de su visita.

Cuando Landívar pasa revista a las aves en el canto XIII, ya vimos que no se detiene en el corral sino para rendir homenaje a Vanière. A lo largo del canto podemos contemplar estampas de la población del aviario que es numerosa pero que no está completa: faltan por lo menos dos habitantes cuya presencia en los campos de la patria de Landívar cifran la identidad del país; me refiero a la variedad de los tucanes, cuyo encendido colorido y desmesurado pico acaban por identificar el paisaje guatemalteco y, en general, el del bosque tropical americano. Pero aún más conspicuo en Guatemala que el vistoso tucán, el quetzal es el ave sagrada entre los mayas desde antes de que llegaran los europeos, símbolo de la libertad hasta nuestros días - muere si enjaulado - e imagen central del escudo de armas guatemalteco. Si algo habría que reprocharle a Landívar sería esta tan inexplicable omisión. Entre los trabajos críticos que conozco, incluidos en la bibliografía, ninguno se ocupa, lo cual también me parece inexplicable, de esta tan visible ausencia.

Esa zona intermedia de la frontera donde parecen convivir el campo y la ciudad es el escenario en el que se efectúan los Ludi en el canto XV. Esos juegos-espectáculos son: la peleas de gallos, las carreras de caballos, las corridas de toros, el juego de los voladores, el palo ensebado y el juego 
de pelota a la usanza indígena, cuyas descripciones dan detallada cuanto colorida cuenta de tan populares justas. El arraigo de la tradición en el campo de los tres primeros - gallos, carreras de caballos y toros- revela el proceso de la "invención" de América pues siendo los tres importados - efectivamente, ya existían los tres en España-, los frutos de su transplante — principalmente la charrería y la fiesta de los toros — iban a ser significantes del nacionalismo mexicano.

Es cierto que los primeros toros bravos no fueron llevados a la Nueva España sólo para divertir a los viejos y a los nuevos aficionados sino también para fortalecer la defensa de las fincas de los nuevos señores contra los ataques y los supuestos robos de los indios a los que les habían arrebatado sus legítimas propiedades. Como la vigilancia de los molosos pronto fue ineficaz pues los indios les tendían trampas y los envenenaban, los señores mandaron traer toros bravos. Cuando los indios tuvieron que defenderse de la acometida de la res, burlándola, nació el toreo mexicano que llegaría a tener un acento distinto del hispano (Pellicer 1998). En este capítulo también saltan a la vista ciertos contrastes entre

\section{LA GRANDEZA Y LA RUSTICATIO}

pues llama la atención que la primera no se refiera ni a las corridas de toros ni a los otros "juegos" descritos por la Rusticatio, que ya serían todos ellos muy populares en la ciudad de México cuando la Grandeza fue escrita y publicada. En cambio, en el canto V, Balbuena da noticia de "regalos, ocasiones de contento" que sólo sugieren diversiones cortesanas. Evidentemente, en la óptica del siglo de Balbuena no caben todavía las expresiones de la cultura popular que deberían servir para presentar la "buena" imagen de la ciudad. Es cierto que en el canto III sí se ocupa de caballos y caballeros, nuestros incipientes charros de entonces, pero sólo de los charros catrines de la ciudad, los "de banqueta", y no de los auténticos charros del campo que son los que describe Landívar en sus carreras. La omisión de toda expresión de cultura popular en la Grandeza revela desprecio (¿ignorancia? ¿esnobismo?) por el valor de los gustos del pueblo. No hay que olvidar que Balbuena y Landívar pertenecían ambos a la alta clase social —aún más encumbrados los Landívar-y ambos militaban en las filas eclesiásticas; sin embargo, la diferencia que separa a los dos autores está en los tiempos —el de la reciente conquista y del zénit 
del imperio hispano, y el de la Ilustración y del surgimiento de una conciencia nacionalista entre los criollos-. Quizás también marque aún más la diferencia la formación jesuita de Landívar tan orientada a las ciencias sociales y a la didáctica. Tampoco hay que olvidar que los festejos populares que omite la Grandeza, unimismaban pues los compartían en el campo y en la ciudad, tanto peninsulares como criollos, mestizos e indios, es decir, eliminaban las barreras sociales. Este hecho, el de unimismar, resultaba básico para la imagen de México que contribuirían a formar los jesuitas ilustrados siglo y medio después.

La mirada de la Grandeza está centrada en la ciudad a la que el campo sirve, en el mejor de los casos, sólo para enmarcarla o como telón de fondo; vimos arriba, al referirnos al canto IV del poema de Balbuena cómo glorifica la vida urbana contrastándola con la supuesta "rudeza" y "torpeza" del pueblo del campo. La mirada de la Rusticatio, en cambio, está puesta principalmente sobre la vida del campo y la de su ejemplar

pueblo trabajador, tanto el humano como el animal. Efectivamente, el ánimo utilitario, didáctico y moralizante de la geórgica contrasta con el espíritu barroco, predominantemente estético en el caso de la Grande$z a$. En cambio, no podríamos calificar ni de utilitaria, didáctica y moralizante, pero tampoco de barroca a la Visión de Anáhuac, de

REYES

Acaso nada haya marcado tan profundamente la vida de Alfonso Reyes, al menos su juventud, como la muerte de su padre el 9 de febrero de 1913 en las puertas de Palacio Nacional y en las de la Revolución Mexicana (Reyes 1963). Nacido en Monterrey en 1889, Reyes terminó su enseñanza primaria en el Liceo Francés de la ciudad de México donde se había mudado la familia; de regreso en Monterrey, comenzó la preparatoria ahí y, de vuelta en la capital del país, la terminó en la Escuela Nacional Preparatoria; luego ingresó a la Facultad de Derecho de la Universidad Nacional. Estrella fulgurante de la joven intelectualidad mexicana reunida en el Ateneo de la Juventud, al tiempo que contraía matrimonio con Manuela Mota (1911), nacía Alfonso, su hijo único (1912) y se recibía de abogado (1913), Reyes tuvo que enfrentarse a una gran encrucijada a la que concurrían diversas circunstancias: la caída del Porfiriato al cual había servido su padre, el general Bernardo Reyes, con 
brillante distinción; la emergencia de la revolución dentro de la cual el joven Reyes desempeñó el cargo de secretario de la Escuela de Altos Estudios; revolución contra la cual se levantó en armas su padre y cayó muerto; el asesinato del presidente Madero y del vicepresidente Pino Suárez motivo por el cual Alfonso renunció a su puesto en la Escuela de Altos Estudios; y el ofrecimiento que el propio Victoriano Huerta le hizo a Alfonso para ser su secretario particular — ofrecimiento que Reyes no aceptó contrariando temerariamente al usurpador (Reyes 1969: 32), Ante tan brutal encrucijada, apunta, "anhelé poner tierra y mar de por medio y alejarme de la vendetta mexicana” (Reyes 1990: 162). En efecto, optó por un puesto en el Servicio Exterior, en otras palabras: un destierro. "Me apresuré a presentar mi tesis para recibir el título de abogado", apunta en su diario, "me dejé nombrar secretario de la Legación en París, y al fin consentí en salir de México el 10 de agosto de 1913" (Reyes 1969: 32), acompañado por Manuelita y por su hijo Alfonso.

En París permaneció hasta octubre de 1914 cuando a causa de la Guerra europea y de "la supresión en masa del Cuerpo Diplomático y Consular Mexicano en el extranjero” (Reyes 1969: 10), se tuvo que ir a Madrid "como Ruiz de Alarcón, a pretender en Corte, a ver si me gano la vida" (Reyes 1969: 38). Pronto quedaron atrás las dificultades económicas de los primeros días en Madrid y comenzó a relacionarse con sus pares de la constelación intelectual madrileña que llegaron a acogerlo como amigo y colega: Ramón Menéndez Pidal, José Ortega y Gasset, Federico de Onís, Américo Castro, Enrique Díez-Canedo, Azorín, Ramón del Valle Inclán, Juan Ramón Jiménez, Ramón Gómez de la Serna y muchos otros. Con ellos colaboró en periódicos, revistas y ediciones de los clásicos españoles destacándose, ya desde entonces, sus brillantes cuanto decisivos estudios sobre Góngora y Ruiz de Alarcón. Otro exiliado en Madrid fue su buen amigo Martín Luis Guzmán; allá vivía también Ángel Zárraga con quien unió a Reyes una estrecha amistad; Diego Rivera, otro amigo suyo, pasó una temporada también en Madrid, en 1915, con su mujer Angelina Beloff. Pero, como el propio Reyes advierte, "por aquellos tiempos, los mexicanos - fuera de Rodolfo Gaona - éramos allá desconocidos” (1990: 167).

No fue la madrileña la primera coincidencia con Diego pues ya se habían encontrado en París donde el pintor guanajuatense vivía cuando Reyes prestaba sus servicios en la legación de México. Pero fue cuando Diego estaba en Madrid que Reyes escribió la Visión. No quiero 
sugerir que Diego haya tenido que ver con la concepción del texto; pero lo que siempre me ha llamado la atención son las grandes afinidades que hay entre el paisaje del valle de México descrito por la Visión y el valle de México plasmado en los murales al fresco de los corredores del Palacio Nacional, particularmente en el denominado "La gran ciudad de Tenochtitlan” que ejecutó Diego en 1945, es decir, treinta años después de la coincidencia en Madrid. La insólita luminosidad del valle y la también insólita transparencia de su aire, vueltas célebres por la $\mathrm{Vi}$ sión, ${ }^{7}$ parecen pasar de la palabra al fresco inalteradas por la traducción de un lenguaje al otro. Y la misma afortunada correspondencia acontece con las escenas urbanas, especialmente con las del mercado.

Desgraciadamente, el diario de Reyes se interrumpe el 10 de octubre de 1914 cuando acababa de llegar a España y se reanuda en México casi diez años después, el 4 de julio de 1924, recién llegado de Madrid, donde había estado adscrito a la legación de México desde 1920, y en vísperas de su traslado a Buenos Aires. Pero no es difícil imaginar "las horas de angustia” que pasó Reyes, según él mismo refiere (1990: 174) durante el período de su aclimatación en Madrid. Horas de angustia que se habrán mezclado con la sensación de la consumación de su independencia: "Quise ser quien era”, concluye, “y no remolque de voluntades ajenas. Gracias a Madrid lo logré" (1990: 177).

En Madrid, empezó Reyes por escribir breves artículos para El Heraldo de Cuba que se publicaron, por primera vez juntos, en México en 1917 bajo el título de Cartones de Madrid. Simultáneamente escribió, en 1915, la Visión. Así lo refiere el propio autor (1990: 178):

Tras ese primer choque o toma de contacto con el ambiente, de que es testimonio el librito Cartones de Madrid, instalado ya con mi familia, aunque modestísimamente, en la calle de Torrijos, el recuerdo de las cosas lejanas, el sentirme olvidado por mi país y la nostalgia de mi alta meseta me llevaron a escribir la Visión de Anábuac (1519).

No creo que hayan sido sólo el olvido y la nostalgia los que impulsaron a Reyes a escribir la Visión. En su estudio sobre cuestiones re-

\footnotetext{
${ }^{7}$ No hay que olvidar que antes de la Visión, durante la segunda parte del siglo XIX y los primeros años del xx, José María Velasco, que fuera maestro del joven Diego Rivera, había dedicado su vida a pintar la luz y la transparencia del aire del valle con insuperable destreza.
} 
ferentes a la identidad de Reyes, Amelia Barili observa (135) que por entonces Ortega y Gasset tildaba a Reyes de "provinciano" porque el regiomontano trataba con cierta insistencia de explicarles a los españoles, en su columna del periódico El Sol, que por cierto era del propio Ortega, lo que en realidad era México desde una perspectiva mexicana. Y uno se pregunta ahora: ¿Cuál de los dos era el "provinciano": el que miraba a México desde afuera, encerrado en Europa, sin conocerlo directamente, o el que siendo mexicano lo miraba desde afuera? Cierto, a pesar de la bienvenida que le brindaron a Reyes en España, no habrá sido fácil para él lidiar a quienes, como diría Antonio Machado, desprecian cuanto ignoran. Y seguramente que el origen de la Visión no es ajeno a esos resabios coloniales.

Dueño de una erudición universal y de un estilo tan diáfano y transparente como el aire de la región a la que cantó, fue Reyes, a juicio de Jorge Luis Borges (Poniatowska: 7), "el mejor prosista (que ha habido) de este y el otro lado del Atlántico". Ningún otro texto entre su obra que cubre prácticamente todos los géneros, ha sido tan difundido en el mundo como la

\section{VISIÓN DE ANÁHUAC}

¿Ensayo? ¿Poesía? ¿Prosa? ¿Poesía en prosa? ¿Poema en prosa? ¿Prosa artística? ¿Garantiza la mera forma —-métrica y ritmo- la existencia de la poesía? No es este el lugar para entretenernos con una discusión sobre géneros literarios. "Las unidades métricas que pone en juego" (el poema en prosa), advierte Rafael Núñez Ramos, "son básicamente las mismas que constituyen el verso libre" (130), y concluye que este tipo de poema suele practicarse "para huir del peligro de ostentar una identificación formal que es utilizada con frecuencia como signo falso de la poesía" (131). Octavio Paz apunta que "no es posible reducir su poesía (la de Reyes) a sus versos; uno de sus poemas es un vasto fresco en prosa, Visión de Anáhuac..." (1971: 25) y Carlos Monsiváis se refiere a la Visión como uno de los "dos grandes poemas" de Reyes (26).

En su estudio sobre la relación de Reyes con España, Barbara Bockus Aponte indica que el propósito de la Visión no es histórico sino fundamentalmente el de una evocación estética de la historia de México (17). Barili opina, por su lado, que lo que Reyes se propone en el texto 
que examinamos "es contrastar visiones autóctonas y foráneas sobre la cultura precolombina anterior a la Conquista de México, e interpretarlas a partir de su propia visión desde una perspectiva latinoamericana” (148). Agrega Barili que "la intensidad de la evocación [....] se basa en [...] su emoción lírica, su nostalgia, intensificada por la lejanía en el tiempo y en el espacio, ya que [...] escribe este ensayo desde su exilio en Madrid" (155).

Valery Larbaud, en la introducción a la traducción al francés de 1927, citada por Reyes (1990: 184), concluye que la Visión es nada menos que "un verdadero poema nacional mexicano" lo cual coincide con la intención de Reyes según él mismo le confía a Antonio Mediz Bolio en una carta de 1922 (1990: 185). Efectivamente, contemplada como un poema en prosa o un ensayo, como una imagen mural, como una lección de mexicanismo, como un poema nacional, como el contraste de visiones autóctonas y foráneas desde una perspectiva latinoamericana, y como fruto de la nostalgia desde el exilio, la Visión representa una de las cumbres en la vasta obra de Reyes.

El texto se publicó por primera vez en San José de Costa Rica, en 1917. El propio Reyes (1990: 180) señala sus fuentes: "las Cartas de Relación de Cortés; la Historia verdadera de la conquista, de Bernal Díaz del Castillo, y la crónica del Conquistador Anónimo, que ahora resulta una invención de Ramusio; lo cual, por suerte, para nada afecta mi ensayo". En cuanto a su forma, el texto consta de cuatro partes siendo la segunda y la tercera las mayores. La primera lleva, para comenzar, un epígrafe que parece dirigirse al lector implícito, en este caso viajero implícito: "Viajero: has llegado a la región más transparente del aire”. Esta que es también una bienvenida al texto, pronto se popularizó en México y se volvió un lugar común, sobre todo del orgullo de los capitalinos, pues efectivamente correspondía todavía a la característica pureza del aire de altura como era el del valle de México cuando la Visión se publicó y casi hasta mediados del siglo Xx. ${ }^{8}$

${ }^{8}$ En 1940, contemplando "los mantos de sepia" que comenzaban entonces a cubrir la ciudad de México, el propio Reyes deconstruye su ya tan famosa transparencia en un artículo titulado "Palinodia del polvo" que comienza con tres preguntas retóricas dirigidas a los desecadores de lagos y taladores de bosques: “¿Es esta la región más transparente del aire? ¿Qué habéis hecho, entonces, de mi alto valle metafísico? ¿Por qué se empaña, por qué se amarillece?” (1981: 61). Casi veinte años después de la "Palinodia", Carlos Fuentes usaría parte del epígrafe para titular una de sus novelas. 
Efectivamente, la primera parte está orientada por la visión del viajero, en este caso, la visión de un europeo y subdividida en cinco secciones que, en este caso, bien pudieran denominarse estrofas. En la primera de ellas, Reyes evoca (13) la ingenuidad y el encanto de las imágenes con las que los europeos ilustraron las primeras obras etnográficas, particularmente la de Ramusio de 1550: barcos diminutos, monstruos marinos, estrellas náuticas, nubes esquemáticas, "un Eolo mofletudo, indicando el rumbo de los vientos", palmeras, chozas, fieras, plantas exóticas, cazadores, pescadores. En la segunda, Reyes recrea poéticamente, es decir, con lenguaje figurado (14), las ilustraciones de las plantas y así recurre a los más afortunados símiles y metáforas.

El tono grave de la tercera sección contrasta con la gracia de las dos primeras ya que aquella está dedicada a presentar el complejo y paradójico problema de las inundaciones y la desecación del valle llevada esta última a cabo, muy simétricamente, por tres razas, tres civilizaciones y tres regímenes monárquicos (al Porfiriato, acaso metafóricamente, lo identifica Reyes con una monarquía). Al final, Reyes concluye (15) primeramente con una imagen poética del agua que la personifica dramatizándola en un escenario en el que el agua irrumpe cabalgando frente al virrey, el arzobispo y los técnicos de la época, y con otra imagen, la final, poblada por la más afortunada elección de adjetivos, que también personifica al agua amenazante.

En la cuarta sección, el viajero es otro: es el americano en Europa que dice Reyes (15) que "está condenado a que los europeos le pregunten si hay en América muchos árboles”. Obviamente la trivial pregunta revela la ignorancia reconocida de los europeos que son provincianos, pero aquí la usa el autor como pretexto para comparar ventajosamente al valle de México con otros lugares, en primer lugar con Castilla. En efecto, según la Visión, comparado con Castilla, el valle es más alto, más armonioso, menos agrio, el aire brilla como espejo y se goza un otoño perenne. Remata Reyes con emoción impresionista: "La llanura castellana sugiere pensamientos ascéticos: el valle de México, más bien pensamientos fáciles y sobrios. Lo que una gana en lo trágico, la otra en plástica rotundidad". Comparado con la selva tropical, también sale ganando el valle. Con visible ironía, Reyes describe (16) la selva parodiando a los europeos - sobre todo los franceses - y obligando al lector a evocar los característicos paisajes naïf de Henri Rousseau. 
El resultado es de esperarse: "Lo nuestro, lo de Anáhuac, es cosa mejor y más tónica. Al menos, para los que gusten de tener a toda hora alerta la voluntad y el pensamiento claro". Lo que acaso resulta más significativo es el empleo del posesivo "nuestro" identificado con Anáhuac, es decir, con el valle de México, y precisado por la afirmación que sigue: "La visión más propia de nuestra naturaleza está en las regiones de la mesa central". De modo que según Reyes, el valle de México es lo más propiamente mexicano, más que la selva y las otras regiones que también forman parte de la nación y que deberían ser tan representativas de México como el valle. En efecto, es este el tradicional sentimiento de superioridad de los pobladores de la capital y de todo el valle, respecto de los demás mexicanos; sentimiento que, por cierto, ya habíamos observado en el poema de Balbuena.

La quinta sección (17) es el preludio de la segunda parte del poema; en aquella ya se prefigura el paisaje, "no desprovisto de cierta aristocrática esterilidad, por donde los ojos yerran con discernimiento, la mente descifra cada línea y acaricia cada ondulación; bajo aquel fulgurar del aire y en su general frescura y placidez", 9 que fue donde encontraron los antiguos mexicanos la prometida águila sobre el nopal devorando una serpiente.

La segunda parte de la Visión lleva como epígrafe la alusión del Amadís que hace Bernal Díaz del Castillo y que sirve a Carpentier para explicar su noción de lo real maravilloso. Esta segunda parte está subdividida también en cinco secciones, todas ellas dedicadas a la gran ciudad de Tenochtitlán como supone Reyes que la encontraron los españoles. En la primera vemos (18-19) la metrópoli azteca "como una inmensa flor de piedra" y toda la dinámica de las calles, los puentes, los canales y las lagunas con sus "piraguas llenas de fruta”. Así, con poética economía y liquidez, Reyes traza rasgos característicos del peculiar tono oral de los indígenas, tono que además corresponde a su fino y suave modo de ser tan diverso del de los conquistadores. Y digo "define", en presente, porque el presente es el tiempo verbal que rige la retórica a lo largo de la Visión. Reyes recrea en esta sección el presente de aquella grandeza mexicana que encuentra en el esplendor de los atavíos aderezados con

\footnotetext{
${ }^{9}$ La descripción, por lo diáfano, corresponde a la de los paisajes del valle que tanta fama le habían dado al entonces recién fallecido José María Velasco. Y, como vimos arriba, volvió a usarla Reyes al referirse a la Grandeza mexicana.
} 
bordados de oro y de plata y de plumas de colores, a veces tornasoles, que luce el moreno pueblo sonriente cuando aparece el emperador.

En la segunda sección, estática, se determinan los tres sitios principales de la gran urbe: templo, mercado y palacio imperial. En la tercera, también de carácter estático, se puede contemplar la maravillosa arquitectura del templo mayor que "alza [...] cuarenta torres, bordadas por fuera, y cargadas en lo interior de imaginería, zaquizamíes y maderamiento picado de figuras y monstruos [...] dentro del templo pudiera caber una villa de quinientos vecinos" (19-20).

Es en la cuarta sección donde Reyes ejecuta (20-23) la brillante escena del mercado y de su peculiar dinámica, único momento cabalmente barroco de la Visión, y que sugiere una probable relación transtextual con el mural de Diego Rivera, "La gran ciudad de Tenochtitlan", aludida arriba. A través de las miradas asombradas de Cortés y de Bernal del Castillo - cuyas crónicas, a su vez, resultan los hipotextos de la Visión - , la pluma de Reyes traza el itinerario entre la muchedumbre de más de sesenta mil almas que diariamente recorre la gran plaza con portales del mercado, dos veces más grande que la soberbia plaza de Salamanca; paralelamente al itinerario, el texto levanta los inventarios de todo lo que se vende. Y junto a las cosas están las figuras humanas de los vendedores, unas sólo agrupadas dentro del anonimato gremial "-los mercaderes rifadores, los joyeros, los pellejeros, los alfareros-" pero otras, como la de la vendedora con vasijas, jarrones, tinajas y ollas, plasmada en sensuales juegos plásticos de intercambiables redondeces y curvas y senos y cinturas y cuellos que conjugándose igualan los colores y los matices del barro y del cuerpo tan cálidamente como el agua hirviendo.

La quinta sección está dedicada a la deslumbrante suntuosidad de la corte de Moctezuma cuyo "reino es de oro, su palacio de oro, sus ropajes de oro, su carne de oro" (24). La abundancia del oro ocupa un primerísimo plano frente a los ávidos ojos europeos. Reyes se complace en detallar el exquisito refinamiento de las costumbres del monarca en la mesa, la sobremesa y, con irónico pudor que ocultando revela, también en la cama. El texto enfrenta a los españoles con estos lujos de la cultura y con las expresiones de respeto con el que los súbditos se dirigían al emperador para poner de relieve que los españoles no estaban acostumbrados a tales refinamientos y para reivindicar así la cultura de las costumbres indígenas. 
La tercera parte está dedicada a la poesía y, paradójicamente, es la más prosaica de las cuatro debido seguramente a que predomina el comentario crítico sobre determinados textos. La Visión concluye en la cuarta parte, que no se extiende más allá de una página, con la expresión de la profunda convicción a partir de la cual se ha enfocado desde el principio dicha Visión: "La emoción histórica es parte de la vida actual y, sin su fulgor, nuestros valles y nuestras montañas serían como un teatro sin luz" (34). Esa emoción es una convicción que, como indica el poeta implícitamente, está más allá de "absurdos" indigenismos o hispanismos; convicción de que, independientemente de una u otra sangre, o de una $u$ otra cultura, hay una tradición común que nos une y que se cifra en "el esfuerzo por domeñar nuestra naturaleza brava y fragosa; esfuerzo que es la base bruta de la historia”. El hecho de mirar este esfuerzo en singular aunque los esforzados estén en plural, es el principio de una perspectiva conciliadora que es la que representa Reyes en su tiempo. Con esa "emoción cotidiana ante el mismo objeto natural" identifica el joven escritor regiomontano autoexiliado en Madrid, la luz que ilumina la imagen del México que quiso enseñarle a los españoles, a quienes, por cierto, tanto quiso. Con este reconocimiento al poder de la emoción histórica y de la imaginación poética, piedra angular del texto, se redondea el puntual remate de Visión de Anábuac.

En efecto, la Visión está compuesta por el juego de dos perspectivas, la de los europeos del siglo XVI y la americana de Reyes del siglo XX; esta última expresada, según el propio Reyes, de modo peculiar pues apuntaba, en otra parte (1952a: 15), que "en mi primera reacción verbal ante los fenómenos de la vida, yo 'siento que siento' en una lengua levemente distinta de la peninsular". Ahí, en la sutil pero profunda emoción de sentir un sentimiento que, como agrega Reyes, implica un cambio de conciencia, se encuentra lo americano de su expresión que muchas veces fue reivindicatoria. En la Visión, es la dialéctica de las dos perspectivas — la de allá y la de acá- la que va creando la imagen —en singular - de Anáhuac, como son también plurales los esfuerzos de indígenas y españoles, de mestizos y criollos, los que históricamente han ido construyendo la singular nación. Así leo la impecable correspondencia del contenido de la imagen de la Visión con su expresión o discurso.

Fue esa emoción histórica y cotidiana con la que cumpliría Alfonso Reyes su vocación de puente entre dos mundos durante toda su vida. 
Sin embargo, no faltó quien le reprochara su desarraigo, sus inclinaciones hacia el helenismo, hacia la literatura francesa, hacia las letras del Siglo de Oro, principalmente las de Góngora, y cuando llegó a denunciarse su "desvinculación de México" (Reyes 1952b: 42), el regiomontano desplegó su elegante y rotunda retórica para exponer sus indudables credenciales de patriota a carta cabal. ${ }^{10}$

A pesar de sus diferencias, podemos confirmar ahora que los tres textos examinados entrañan

\section{APOLOGÍAS REIVINDICATORIAS}

Hemos podido comprobar que, como lo sugiere la compleja reflexión postcolonial de nuestros días, el lenguaje ha contado con un poder decisivo para construir la imagen del mundo colonizado y para así dominarlo —o reivindicarlo—, y que el significado de los textos poéticos trasciende su ámbito meramente literario. Lo confirman los de Balbuena, de Landívar y de Reyes aquí comentados pues ofrecen lecturas que revelan significados implícitos relativos al desarrollo del ánimo reivindicatorio americano durante el lapso de casi ciento ochenta años que separan a los dos primeros textos examinados y de casi ciento cuarenta a los dos últimos. Los tres textos pueden leerse como apologías que reivindican, desde la otra ladera, el valor de lo americano frente a la mirada hegemónica eurocentrista.

También hemos observado la paradoja que entraña la expropiación del lenguaje poético dominante para convertirlo en lenguaje reivindicatorio, el español del barroco en el caso de la Grandeza, el latín virgiliano y vanerieno en el de la Rusticatio y el diáfano español moderno en el de la Visión. No se trata de la mera vía imitativa, sino de una recreación que es en lo que consistió el nombramiento de las cosas para explicar el nacimiento del lenguaje poético americano en español. Estos tres textos nos muestran cómo el español comenzaría a naturalizarse americano, cómo el latín también iba a hacerlo y cómo el moderno español ya estaría plenamente naturalizado: los tres iban a formar parte de tradiciones culturales que ya no serían ni exclusivas de España ni de Roma, es decir, tan nuestras como de ellos. Aún más: en la plu-

\footnotetext{
${ }^{10}$ Sobre la polémica nacionalista de esos días, ver Sheridan, 1999: 49-67 y 94-102.
} 
ma de Landívar, el latín no sólo reivindicaría lo que el ciego eurocentrismo se había empeñado en menospreciar sino que su uso implicaría la afirmación de una tradición que ni el rey de España ni el Papa podían negarle o arrebatarle.

La lectura de estos poemas revela la mudanza de la patria; si para el cura-poeta del Siglo de Oro seguía estando en España, en donde cifraba el origen de la grandeza mexicana, para el poeta-jesuita del Siglo de las Luces - y desde luego para el erudito regiomontano del siglo $\mathrm{XX}-$ ya estaba en América y la grandeza mexicana tenía su origen en el pasado prehispánico. Recuérdese la imagen "temerosa" y "espantosa", "intratable y feroz" de "el indio feo" que presenta la Grandeza desde una perspectiva aún europea que contrasta con la evocación que hacen la Rusticatio y la Visión, más americana que europea, de Tenochtitlan, magnífica gracias a sus pobladores y gobernantes indígenas. Pero el "indigenismo" de Landívar no se limita, como el indigenismo mexicano moderno, a la glorificación del pasado indígena prehispánico y a la imposición de la cultura europea a los indígenas del presente —es decir, a los vivos - como requisito para incorporarlos a la vida nacional (Bonfil Batalla: 161-186; Montemayor: 75); en efecto, Landívar también admira a los indígenas de su época — sus contemporáneos—, y no pierde oportunidad para elogiar su cultura y su ingenio.

En el significado que proyecta el discurso de cada uno de los tres poemas se cifra la dinámica del diálogo — hegemonía/reivindicaciónque implica la invención de América, en tres épocas distintas - el Siglo de Oro, el de las Luces y el de la Revolución Mexicana-y desde dos realidades distintas — las dos laderas del océano—, diálogo en el cual ha transcurrido el proceso de la apropiación y recreación de un lenguaje poético, es decir, el de su invención.

\section{BibLIOGRAFíA}

AshCRoft, B. "Modernity's first born: Latin America and post-colonial transformation", en El debate de la postcolonialidad en Latinoamérica. A. de Toro y F. de Toro (eds.). Madrid: Iberoamericana, 1999.

Aponte, B. B. Alfonso Reyes and Spain. Austin / London: University of Texas Press, 1972.

Asturias, Miguel ÁNGel. "La novela latinoamericana: testimonio de una época", en América, fábula de fábulas. Caracas: Monte Ávila Editores, 1972. 
Balbuena, Bernardo De. La grandeza mexicana. México: Editorial Porrúa, 1971.

BARILI, A. Jorge Luis Borges y Alfonso Reyes: la cuestión de la identidad del escritorlatinoamericano. México: Fondo de Cultura Económica, 1999.

Batllori, M. La cultura hispano-italiana de los jesuitas expulsos. Madrid: Gredos, 1966.

Bonfil Batalla, Guillermo. México profundo. México: Grijalbo, 1990.

Buxó, Pascual. "Bernardo de Balbuena: el arte como artificio", en Homenaje a José Durand. Luis Cortest (ed.). Madrid: Verbum, 1993.

Cardoza y Aragón, Luis. El río. México: Fondo de Cultura Económica, 1986.

Carpentier, Alejo. "Lo barroco y lo real maravilloso", en Razón de ser. Caracas: Universidad Central de Venezuela, 1976.

Henríquez Ureña, Pedro. Las corrientes literarias en la América Hispánica. Trad. Joaquín Díez-Canedo. México: Fondo de Cultura Económica, 1978.

Higgins, A. Constructing the Criollo Archive: Subjects of Knowledge in the Biblotheca Mexicana and the Rusticatio Mexicana. Indiana: Purdue University Press, 2000.

Kerson, A. L. "Rafael Landívar's Rusticatio Mexicana and the Enlightment in America", en Acta Conventus Neo-Latini Sanctandreani. Medieval and Renaissance Texts and Studies. 38, 1986.

LaIrD, A. The Epic of America. An Introduction to Rafael Landivar and the Rusticatio Mexicana. London: Duckworth, 2006.

Landívar, Rafael. Por los campos de México. O. Valdés (ed.). México: Universidad Nacional Autónoma de México, 1973.

- Rusticatio Mexicana. F. Chamorro (ed.). San José de Costa Rica: Libro Libre, 1987.

Menéndez Pelayo, Marcelino. Historia de la poesía hispano-americana. I. Madrid: Librería General de Victoriano Suárez, 1911.

Monsiváis, Carlos. La poesía mexicana del siglo XX. México: Empresas Editoriales, 1966.

Montemayor, Carlos. "La invención europea de América y de México I", en Proceso. 1210. (México, 9 de enero de 2000). 72-75.

Núńez Ramos, R. La poesía. Madrid: Editorial Síntesis, 1998.

O’Gorman, Edmundo. La invención de América. México: Fondo de Cultura Económica, 2002.

Paz, Octavio. El arco y la lira. México: Fondo de Cultura Económica, 1970.

- Las peras del olmo. Barcelona: Seix Barral, 1971.

- El laberinto de la soledad. México: Fondo de Cultura Económica, 1976. 
Pellicer, Juan. "La recreación mexicana de la más peculiar expresión de la cultura popular hispana", en Corriente del Golfo 3-4. Bergen: Universitet di Bergen, 1998.

Poniatowska, Elena. "Borges y 'Don Alfonso'”, en Jorge Luis Borges y Alfonso Reyes: la cuestión de la identidad del escritor latinoamericano. A. Barili (ed.). México: Fondo de Cultura Económica, 1999.

Rangel, N. Historia del toreo en México. México: Imprenta Manuel León Sánchez, 1924.

Reyes, Alfonso. "Psicología dialectal", en La X en la frente. México: Porrúa y Obregón, 1952a.

- "A vuelta de correo", en La X en la frente. Porrúa y Obregón, 1952b.

- Visión de Anáhuac, en Obras completas de Alfonso Reyes, II. México: Fondo de Cultura Económica, 1956.

- "Tentativas y orientaciones", en Obras completas de Alfonso Reyes, XI. México: Fondo de Cultura Económica, 1960a.

- "Letras de la Nueva España”, en Obras completas de Alfonso Reyes, XII. México: Fondo de Cultura Económica, 1960b.

- Oración del 9 de febrero. México: Ediciones Era, 1963.

- Diario 1911-1930. México: Universidad de Guanajuato, 1969.

- "Palinodia del polvo", en Obras completas de Alfonso Reyes, XXI. México: Fondo de Cultura Económica, 1981.

- "Historia documental de mis libros", en Obras completas de Alfonso Reyes, XXIV. México: Fondo de Cultura Económica, 1990.

- "Varia", en Obras completas de Alfonso Reyes, XXV. México: Fondo de Cultura Económica, 1991.

Rojas Garcidueñas, J. Bernardo de Balbuena. La vida y la obra. México: UniversidadNacional Autónoma de México, 1958.

Sheridan, Guillermo. México en 1932: la polémica nacionalista. México: Fondo de Cultura Económica, 1999.

Virgilio, Georgics. Bury St Edmundo: St Edmundsbury Press, 1994.

Wardropper, B. W. "Temas y problemas del barroco español", en Historia y crítica de la literatura española III. Barcelona: Crítica, 1983. 